\title{
Različiti pogledi na eksponencijalnu i logaritamsku funkciju
}

\author{
Nikola Koceić-Bilan, Ivana Lončar
}

\section{Sažetak}

U ovom radu donosimo pregled matematičkih ideja i koncepata metodički poredanih u smislenu cjelinu i potrebnih za obradu nastavnih jedinica potencije, eksponencijalne i logaritamske funkcije u osnovnoj i srednjoj školi. Također, navodimo neka svojstva ovih funkcija i zanimljivosti vezane uz njih s povijesnog i matematičkog aspekta, ali i iz kuta nematematičara koji koriste ove funkcije u različitim primjenama.

Ključni pojmovi: potencija, eksponencijalna funkcija, logaritamska funkcija, kurikul

\section{Eksponencijalna i logaritamska funkcija u kurikulu}

Eksponencijalna i logaritamska funkcija obvezni su dio kurikula [3] u svim srednjim školama. Iako u školskim udžbenicima možemo pronaći neke primjere primjena eksponencijalne funkcije, učenici često ne prepoznaju ulogu eksponencijalne i logaritamske funkcije u ostalim predmetima i znanstvenim disciplinama. Budući da je primjena ovih funkcija u svakodnevnom životu česta, na nastavnicima je matematike zadaća da učenike na adekvatan način upoznaju s matematičkim konceptima potrebnima za razumijevanje njihove definicije i svojstava. Uspješno ostvarivanje zadanih obrazovnih ishoda iz ovih nastavnih jedinica, odnosno usvajanje matematičkih znanja o eksponencijalnoj i logaritamskoj funkciji, u perspektivi omogućuje učenicima njihovu primjenu u fizici, 
ekonomiji, statistici i svugdje gdje se ovim funkcijama mogu modelirati različite životne situacije i procesi. U ovomu odjeljku donosimo pregled spomenutih matematičkih ideja i koncepata metodički poredanih u suvislu cjelinu. Sve navedeno se, uz poštivanje načela postupnosti i primjerenosti, izvodi u skladu s nastavnim kurikulom kroz nekoliko razreda osnovne i srednje škole. Ovdje ističemo okvirnu matematičkometodičku pozadinu gradiva s odgovarajućim primjenama te neke matematičke suptilnosti o kojima se pri artikulaciji nastavnog sata ne vodi dovoljno računa, a koje su bitne za razumijevanje prirode ovih funkcija koje imaju istaknuto mjesto u svakom obrazovnom procesu.

Rad se zasniva na rezultatima iznesenima u diplomskom radu Ivane Lončar 2, studentice diplomskog studija Matematika i fizika; smjer nastavnički Prirodoslovno-matematičkog fakulteta u Splitu, i njezina mentora Nikole Koceića-Bilana.

\subsection{Eksponencijalna funkcija}

Pojam potencije, bez eksplicitnog spominjanja eksponencijalne funkcije, učenici prvi put susreću u osmom razredu osnovne škole. Potrebno ju je uvesti na odgovarajuci način koji odgovara razini primjerenoj učenicima osnovne skole. Jedan je od načina motivirati ih zanimljivom pričom ili problemom. Vrlo često se kao motivacijska priča koristi poznata legenda o šahu i eksponencijalnom rastu broja zrna pšenica stavljenih na šahovska polja. Danas bi još aktualnije bilo osvrnuti se na značenje eksponencijalnog rasta broja ljudi zaraženih virusom.

U osnovnoj se školi definiraju vrijednosti $a^{x}, x \in \mathbb{Z}$. Računsku radnju u kojoj realan broj $a$ množimo samim sobom $n$ puta nazivamo potenciranje. Oznakom $a^{n}, a \in \mathbb{R}, n \in \mathbb{N}$ označavamo potenciju broja $a$, pri čemu $a$ nazivamo bazom, a $n$ eksponentom i ona predstavlja prikratu za nepraktičan zapis pomoću množenja. Ovdje je potrebno naglasiti važnost asocijativnosti množenja realnih brojeva zbog koje je definicija potencije korektna. Upravo ovo svojstvo, koje učenici uzimaju „zdravo za gotovo” i nisu svjesni njegove važnosti, ključno je kod uvođenja potencija. Naime, zbog asocijativnosti vrijedi

$$
a \cdot(a \cdot \ldots \cdot a)=(a \cdot \ldots \cdot a) \cdot a
$$

pa je redoslijed množenja broja $a$ nebitan, što omogućuje uvođenje oznake $a^{n}$. Potencije jednakih baza množimo tako da bazu prepišemo, a eksponente zbrojimo:

$$
a^{m} \cdot a^{n}=a^{m+n}, a \in \mathbb{R}, m, n \in \mathbb{N},
$$

što je učenicima 8. razreda ne samo lako pamtljivo, već i jednostavno dokazivo pravilo preko spajanja dva zapisa potencija pomoću množenja 
i prebrojavanja faktora.

Isto vrijedi i za dijeljenje potencija s jednakim bazama. Pravilo

$$
a^{m}: a^{n}=a^{m-n}, a \in \mathbb{R}, m, n \in \mathbb{N}, m>n,
$$

lako se pamti i dokazuje prebrojavanjem faktora koji nedostaju u dugom zapisu od $a^{n}$ do $a^{m}$. Nadalje, za $m=n$ po tom bi istom pravilu bilo

$$
a^{n}: a^{n}=a^{n-n}=a^{0}
$$

s jedne strane, odnosno

$$
a^{n}: a^{n}=1
$$

s druge strane, pa je prirodno staviti

$$
a^{0}:=1, a \in \mathbb{R} \backslash\{0\}
$$

Slično, iz

$$
\frac{1}{a}=\frac{a^{0}}{a}=a^{0-1}=a^{-1}
$$

slijedi da je prirodno recipročnu vrijednost broja $a$ pisati u obliku potencije na sljedeći način

$$
a^{-1}:=\frac{1}{a}, a \in \mathbb{R} \backslash\{0\}, n \in \mathbb{N} .
$$

Generalizacijom prethodnoga pravila jednakosti slijedi

$$
a^{-n}:=\left(\frac{1}{a}\right)^{n}, a \in \mathbb{R} \backslash\{0\}, n \in \mathbb{N} .
$$

Ovdje je učeniku bitno skrenuti pozornost na to da prethodni izvodi ne vrijede za bazu $a=0$ i da se za takvu bazu potencija s negativnim eksponentom ne definira. Pravilo potenciranja

$$
\left(a^{m}\right)^{n}=a^{m \cdot n}, a \in \mathbb{R} \backslash\{0\}, m, n \in \mathbb{N},
$$

također je lako pamtljivo i elegantno se dokaže prebrojavanjem faktora od $n$ spojenih zapisa pomoću množenja potencija $a^{m}$. Nadalje, pravilo množenja potencija različitih baza, a istih eksponenata

$$
(a \cdot b)^{n}=a^{n} \cdot a^{n}, n \in \mathbb{N},
$$

analogno se dokaže uz korištenje svojstva komutativnosti realnih brojeva. Na ovaj se ukratko opisani način, koji je matematički korektan i intuitivan, učenicima u osnovnoj školi uvodi potencija s cjelobrojnim 
eksponentima i realnom bazom (bez nule za eksponente iz $\mathbb{Z} \backslash \mathbb{N}$ ) te se dokazuju njihova esencijalna svojstva: (1), 22), (3) i (4). Konceptualno smo time zapravo definirali eksponencijalnu funkciju na skupu cijelih brojeva s bazom $a \in \mathbb{R} \backslash\{0\}$. U prvom se razredu srednje škole, po novomu kurikulu, potencija još detaljnije proučava, pri čemu se jednako intuitivno može pokazati da vrijede ista svojstva množenja, dijeljenja i potenciranja potencija i s cjelobrojnim eksponentima. Osim uvježbavanja vještine manipuliranja potencijama, bitno je uočiti prirodnost definicije potencije s negativnim cjelobrojnim eksponentom kao i njezina svojstva koja su ostala ista i nakon njihova proširenja sa skupa prirodnih na skup cijelih brojeva. Upravo zadržavanje ovih lijepih svojstava treba biti misao vodilja pri daljnjim proširivanjima eksponencijalne funkcije na skup racionalnih, a potom i na skup realnih brojeva, koja se obrađuju u 3. razredu srednje škole.

U trećem se razredu srednje škole eksponencijalna funkcija konačno i eksplicitno definira. Pojam potencije su do tada učenici već trebali dobro usvojiti. Uvođenjem eksponencijalne funkcije usustavljuje se pojam potencije i svi se zapisi različitih potencija s istom bazom svode pod istu funkciju. Zapravo se već definirana funkcija na $\mathbb{Z}$ proširuje na skup $\mathbb{Q}$, odnosno definiraju se vrijednosti $a^{x}, x \in \mathbb{Q} \backslash \mathbb{Z}$. U tu je svrhu od matematičke teorije nastavniku potreban teorem o postojanju i jedinstvenosti korijena s kojim se učenici upoznaju (ne nužno s formalnim iskazom) u 8. razredu (drugi korijen, teorem 1), odnosno u 1. razredu srednje škole ( $n$-ti korijen, teorem 2).

Teorem 1. Neka je $a \in \mathbb{R}, a \geq 0$. Tada postoji točno jedan $x \in \mathbb{R}$, $x \geq 0$, takav da je $x^{2}=a$. Broj $x$ označujemo $s \sqrt{a} i$ nazivamo drugim korijenom iz a.

Broj $\sqrt{a}$ htjeli bismo zapisati u obliku potencije $a^{p}$, ali tako da se i za takve potencije zadrže dobro poznata svojstva (1), (2), (3) i (4) ekponencijalne funkcije na skupu cijelih brojeva. Tada imamo:

$$
a^{1}=a=\left(a^{p}\right)^{2}=a^{p} \cdot a^{p}=a^{p+p}=a^{2 p} \Rightarrow 2 p=1 \Rightarrow p=\frac{1}{2} .
$$

Dakle, prirodno je staviti $a^{\frac{1}{2}}:=\sqrt{a}$. Opravdanost ovakvog zapisa korijena učenicima je možda najlakše uočiti i prihvatiti uz takvu motivaciju. Uz sličnu se argumentaciju uvodi zapis $n$-tog korijena pomoću potencije

$$
a^{\frac{1}{n}}:=\sqrt[n]{a}, a \geq 0,
$$

korektnost kojega jamči sljedeći teorem.

Teorem 2. Neka je $a \in \mathbb{R}, a \geq 0$ i $n \in \mathbb{N}$. Tada postoji točno jedan $x \in \mathbb{R}, x \geq 0$ takav da je $x^{n}=a$. Broj $x$ označujemo $s \sqrt[n]{a}$ i nazivamo n-tim korijenom iz a. 
Budući da vrijedi $(\sqrt[n]{a})^{m}=\left(\sqrt[n]{a^{m}}\right)$, uzimajući u obzir $(3)$, prirodno je definirati

$$
a^{\frac{m}{n}}:=(\sqrt[n]{a})^{m}=\sqrt[n]{a^{m}}, a \geq 0, m, n \in \mathbb{N}
$$

Time smo napravili pripremu za uvođenje (proširenje već definirane funkcije na $\mathbb{Z}$ ) funkcije $f_{a}: \mathbb{Q} \rightarrow \mathbb{R}, f_{a}(x)=a^{x}, a \in \mathbb{R}^{+} \backslash\{1\}$, koju nazivamo eksponencijalnom funkcijom na $\mathbb{Q}$. Pokaže se da ovako definirana eksponencijalna funkcija na $\mathbb{Q}$ ima ista svojstva kao i njezino suženje na $\mathbb{Z}$ s kojima su učenici upoznati. Očekujemo da ta svojstva, (1), (2), (3) i (4), vrijede i nakon proširenja eksponencijalne funkcije sa $\mathbb{Z}$ na $\mathbb{Q}$ jer smo ista očekivanja ugradili i u definiciju (5).

Teorem 3. Neka su $a, b \in \mathbb{R}^{+} \backslash\{1\}$. Tada vrijedi:

(i) $f_{a}(x) \cdot f_{a}(y)=f_{a}(x+y)$, za sve $x, y \in \mathbb{Q}$

(ii) $f_{a}(x): f_{a}(y)=f_{a}(x-y)$, za sve $x, y \in \mathbb{Q}$

(iii) $f_{f_{a}(x)}(y)=f_{a}(x \cdot y)$, za svaki $x \in \mathbb{Q} \backslash\{0\}, y \in \mathbb{Q}$

(iv) $f_{a b}(x)=f_{a}(x) \cdot f_{b}(x)$.

Ovdje treba skrenuti pozornost na to da pojam potencije s bilo kojom bazom $\mathrm{s}$ prirodnim eksponentom ima smisla. Isto tako potencija $\mathrm{s}$ bilo kojom bazom osim nule ima smisla za bilo koji cjelobrojni eksponent. Kod racionalnih eksponenata ograničavamo se samo na nenegativne baze različite od 1 . Naime, sve potencije s bazom 1 imaju vrijednost 1 pa bi pripadna eksponencijalna funkcija bila konstanta. Nadalje, iako se potencije s negativnom bazom mogu definirati i za razlomke oblika $\frac{1}{n}$, gdje je $n$ neparan prirodni broj, kao $n$-ti korijen iz apsolutne vrijednosti baze s negativnim predznakom (to se nerijetko i radi), bolje je to izbjegavati. Naime, ako tako definiramo $n$-ti korijen iz negativnoga broja za neki neparni $n$, onda zapis (5) treba uzimati formalno i s dosta opreza. Razlog tomu nije samo to što nema nekog smisla promatrati funkcije s takvom krnjom domenom koja se sastoji samo od cijelih brojeva i racionalnih brojeva oblika $\frac{1}{n}$, gdje je $n$ neparan prirodni broj. Naime, korištenjem takva zapisa učenik bi se lako doveo u zabludu (a vjerojatno i sam nastavnik) oko korektnosti definicije takve potencije koja nije u skladu sa svojstvima potencija s pozitivnom bazom. Naime, primjenjujući svojstvo eksponencijalne funkcije na $\mathbb{Q}$ iz teorema 3 moglo bi se „dokazati” da je primjerice

$$
-2=(\sqrt[3]{-8})=(-8)^{\frac{1}{3}}=(-8)^{\frac{2}{6}}=\left((-8)^{2}\right)^{\frac{1}{6}}=64^{\frac{1}{6}}=2 .
$$

Prodiskutirajmo ispravnost prethodnog niza jednakosti. Prva jednakost $-2=(\sqrt[3]{-8})$ je korektna i podrazumijeva proširenje domene funkcije $n$-tog korijena na cijeli $\mathbb{R}$, za neparni $n$. Naime, teorem 2 omogućuje 
definiranje funkcije korijena $\sqrt[n]{ }:[0, \infty\rangle \rightarrow[0, \infty\rangle$, za svaki $n \in \mathbb{N}$. No, za neparni $n$ možemo sasvim korektno napraviti proširenje takve funkcije korijen na cijeli skup $\mathbb{R}$ pravilom

$$
\sqrt[n]{x}:=-\sqrt[n]{|x|}, x<0,
$$

jer i u tom slučaju vrijedi $(\sqrt[n]{x})^{n}=x$. Druga jednakost $(\sqrt[3]{-8})=(-8)^{\frac{1}{3}}$ je sporna jer smo u (5) korijen prikazali potencijom samo za nenegativnu bazu. Ipak, ako dopustimo korištenje takvoga zapisa i za negativnu bazu onda treba voditi računa da je on formalan i da ta potencija ne predstavlja zapis eksponencijalne funkcije koja je definirana samo za baze $a \in \mathbb{R}^{+} \backslash\{1\}$. Stoga za takve potencije ne vrijede svojstva eksponencijalne funkcije iz teorema 3 , a upravo smo svojstvo (iii) toga teorema nekorektno iskoristili u četvrtoj nejednakosti $(-8)^{\frac{2}{6}}=\left((-8)^{2}\right)^{\frac{1}{6}}$. Dakle, sa zapisom $n$-tog korijena $\sqrt[n]{a}$, za neparni $n$, iz negativnog broja $a$, pomoću potencije $a^{\frac{1}{n}}$ i učenici i nastavnici trebaju biti vrlo oprezni.

Sljedeće je pitanje ima li eksponencijalna funkcija $f_{a}: \mathbb{Q} \rightarrow \mathbb{R}$ proširenje $\tilde{f}_{a}: \mathbb{R} \rightarrow \mathbb{R}$ koje bi zadržalo sva ona ista svojstva koja ima i $f_{a}$ te je li ono jedinstveno?

U trećem razredu srednje škole uvodi se funkcija

$$
\exp _{a}: \mathbb{R} \rightarrow\langle 0, \infty\rangle, \exp _{a}(x)=a^{x},
$$

koju nazivamo eksponencijalna funkcija s bazom $a \in \mathbb{R}^{+} \backslash\{1\}$. Ovu funkciju nije moguće definirati kao neprekidno proširenje funkcije $f_{a}: \mathbb{Q} \rightarrow \mathbb{R}$ i to ne samo jer je o pojmu neprekidnosti preuranjeno govoriti prije četvrtoga razreda srednje škole već jer nam niti jedan teorem matematičke analize ne jamči egzistenciju takvog proširenja (osim za jednoliko neprekidne funkcije, što eksponencijalna funkcija $f_{a}$ nije). Iz matematičke analize znamo da je takvo proširenje jedinstveno, ako ono postoji.

Teorem 4. Neka je $f: \mathbb{Q} \rightarrow \mathbb{R}$ neprekidna funkcija. Ako postoji njezino neprekidno proširenje na $\mathbb{R}$, tj. neprekidna funkcija $\tilde{f}: \mathbb{R} \rightarrow \mathbb{R}$ takva da je $\left.\tilde{f}\right|_{\mathbb{Q}}=f$, ono je jedinstveno.

To se može na intuitivnoj razini predočiti zamišljanjem svih točaka grafa ove funckije (s racionalnim eksponentima) u koordinatnom sustavu koje su toliko guste da je njihova nadopuna s preostalim točkama s (iracionalnim eksponentima) „potpunim grafom” moguća na jedan jedini način. Ipak je uvođenje eksponencijalne funkcije u srednjoj školi nemoguće napraviti na precizan i matematički strog način, pa se najčešće proširenje eksponencijalne funkcije sa skupa racionalnih na skup realnih brojeva prešuti ili se učeniku ostavi apstraktna predodžba o nadopuni grafa. 
Zbog toga će rijetko koji učenik biti u stanju objasniti što je to npr. $10^{\sqrt{2}}$ ili makar numerički procijeniti tu vrijednost. Dodajmo da se kod uvođenja trigonometrijskih funkcija u kurikulu inzistira na strogom definiranju funkcijskih vrijednosti za sve realne brojeve. Za slučaj eksponencijalne funkcije takoder bi trebalo inzistirati na makar intuitivnom definiranju njezinih vrijednosti u iracionalnim argumentima. Dakle, pojasniti pravilo pridruživanja

$$
x \mapsto a^{x}, x \in \mathbb{I},
$$

odnosno kako u trećem razredu srednje škole definirati vrijednosti eksponencijalne funkcije za iracionalne argumente predstavlja metodički izazov svakom nastavniku matematike pred kojim ne bi trebao lakonski zatvarati oči.

Iako se učenici s pojmom konvergencije niza i limesom niza susreću tek u četvrtom razredu srednje škole, na intuitivnoj razini može im se pojasniti vrijednost $10^{x}$ eksponencijalne funkcije $\exp _{10} \mathrm{~s}$ iracionalnim argumentom $x$ pomoću niza njezinih vrijednosti s racionalnim argumentima koji konvergiraju prema $x$. Pogledajmo to na primjeru vrijednosti $10^{\sqrt{2}}$. Vrijedi: $\sqrt{2}=1.414213562 \ldots$ i $10^{\sqrt{2}}=25.95455352 \ldots$

Promotrimo niz vrijednosti eksponencijalne funkcije $\exp _{10}$ za racionalne argumente koje su sve bliže vrijednosti $\sqrt{2}$, odnosno za članove niza $1,1.4,1.41, \ldots$ kojemu $n$-ti član ima točno $n-1$ decimala i to jednakih onima broja $\sqrt{2}$ :

$$
\begin{aligned}
10^{1} & =10 \\
10^{1.4} & =10^{\frac{14}{10}}=25.11886432 \ldots \\
10^{1.41} & =10^{\frac{141}{100}}=25.70395783 \ldots \\
10^{1.414} & =10^{\frac{1414}{1000}}=25.94179362 \ldots \\
10^{1.4142} & =10^{\frac{14142}{10000}}=25.953743013 \ldots \\
10^{1.41421} & =10^{\frac{141421}{100000}}=25.95434062 \ldots
\end{aligned}
$$

Primjećujemo da se sve boljim racionalnim aproksimacijama broja $\sqrt{2}$ sve više decimala u eksponencijalnim vrijednostima ponavlja. Naravno, razlika između članova niza sve je manja, što znači da je niz Cauchyjev, a to opet povlači da je konvergentan. No, iskustvu srednjoškolca je sasvim prihvatljivo i razumljivo da ćemo u decimalnom zapisu vrijednosti broja $10^{\sqrt{2}}$ dobiti više točnih decimala ako izračunamo vrijednost $10^{x}$ za racionalni $x$ koji što bolje aproksimira $\sqrt{2}$, odnosno koji je $n$-ti član promatranog niza za što veći $n$, pa ima što više (točnih) decimala argumenta $\sqrt{2}$. Na takav smo način doprijeli do eksponencijalne funkcije 
s bazom a (6). Sva najvažnija svojstva eksponencijalne funkcije koja se obrađuju u srednjoj školi donosimo u sljedećem teoremu.

Teorem 5. Eksponencijalna funkcija $\exp _{a}$ neprekidna je bijekcija, koja je strogo uzlazna za $a>1$, a strogo silazna za $a \in\langle 0,1\rangle$.

Drugi je izazov pri obradi ovih nastavnih cjelina kako učenicima približiti eksponencijalnu funkciju kroz neku od njezinih brojnih primjena u različitim sferama ljudskog života. Kao prijedlog motivacije pri obradi potencija u srednjoj školi dajemo sljedeća dva primjera.

Zadatak: Cijena majice u trgovini prije sniženja iznosi $160 \mathrm{kn}$. Ako u periodu od 8 mjeseci svakog mjeseca majica pojeftini za 10\%, koliko će iznositi cijena majice na kraju 5., a koliko na kraju 8. mjeseca?

Zadatak: Iako se u nastavi matematike vrlo rijetko koriste eksperimenti, možemo povezati sat matematike sa satom fizike $i$ napraviti eksperiment koji će učenici izvoditi. Na taj ćemo način učenike aktivirati i uključiti u nastavu. Pomoću realnog problema promatrat ćemo veličine koje ovise jedna o drugoj. Kao primjer uzet ćemo odnos promjena temperature u određenom vremenu. Učenici će skuhati čaj. Skuhani će čaj biti na temperaturi od $100^{\circ} \mathrm{C}$. Nakon što je čaj skuhan, učenici će ga početi hladiti $i$ zapisivati promjenu temperature nakon 1 minute, 2 minute, 4 minute, itd. Podatke će prikazati tablično i potom pokušati odgovoriti na pitanje o temperaturi čaja nakon 0.5 minuta, 3 minute $i 8$ minuta.

U oba je navedena zadatka potrebno pronaći odgovarajući matematički model kojim bi opisali zadane probleme, odnosno funkciju koja će povezati dane podatke. U prvom zadatku funkcija $f(x)=160 \cdot(0.9)^{n}$ egzaktno računa cijenu artikla nakon $n$ mjeseci. Iako učenik može točno izračunati cijenu majice za svaki pojedini mjesec odmah je jasan značaj pronalaska odgovarajuće funkcije kojom bismo dobili jedinstveni algoritam za računanje cijene na kraju bilo kojega mjeseca. U drugom zadatku nije tako jednostavno odrediti odgovarajući model. Potrebno je znati da se navedeni fizikalni proces hlađenja približno odvija po eksponencijalnom modelu, odnosno po nekoj funkciji $f(x)=a b^{x}+c$, a empirički treba odrediti najpogodnije konstante $a, b$ i $c$. U ovom slučaju teško možemo odabrati koeficijente takve da funkcija za određeni argument $x$ (trenutak mjerenja) ima vrijednost točno jednaku izmjerenoj temperaturi čaja, ali zadovoljit ćemo se time da su dobivene vrijednosti približno jednake. Za takvu funkciju svejedno možemo reći da predstavlja model zadanog realnog problema. Isti može poslužiti za približno određivanje temperatura čaja i u neizmjerenim trenutcima, odnosno za anticipiranje temperature čaja u nekim daljnjim trenutcima, kao i za interpoliranje temperature $u$ nekom vremenu između dva mjerenja. Ovakvi zadatci 
mogu poslužiti za bolje razumijevanje matematičkog modeliranja problema iz svakodnevnog života. No, ostaje pitanje kako za pojedini problem odabrati odgovarajući model. Osim iskustveno i temeljem poznavanja svojstava određenih prirodnih procesa, prikladni model možemo prepoznati po međuodnosu empiričkih podataka. Upotreba linearnog i eksponencijalnog modela u srednjoškolskoj nastavi česta je u različitim primjenama. Karakteristika je linearnog modela konstantnost razlika vrijednosti funkcije na krajevima intervala jednake duljine. Karakteristika eksponencijalnog modela jest konstantnost kvocijenta vrijednosti na krajevima intervala jednake duljine. Promotrimo primjer linearnog i eksponencijalnog modela na aktualnom slučaju epidemije.

Primjer 6. Neka je na početku (nulti dan) epidemije bila samo jedna zaražena osoba. Ako se svaki sljedeći dan zaraze po dvije nove osobe, onda linearni model zadan funkcijom $f(x)=x+2$ precizno opisuje broj zaraženih po danima i kažemo da je rast zaraženih linearan, odnosno broj novooboljelih je konstantan. Ako se svaki sljedeći dan zarazi dva puta više ljudi nego li ih je bilo prethodnog dana, onda eksponencijalni model zadan funkcijom $f(x)=2^{x}$ egzaktno opisuje broj zaraženih po danima $i$ kažemo da je rast zaraženih eksponencijalan. Primijetimo da je $i$ broj novooboljelih svakog dana također eksponenijalan. Zaista, $2^{x+1}-2^{x}=2^{x}$ je broj novooboljelih $u$ danu $x+1$ u odnosu na dan $x$.

\subsection{Logaritamska funkcija}

Logaritamska se funkcija u nastavi matematike prvi put uvodi u trećem razredu srednje škole. Nakon detaljne obrade eksponencijalne funkcije uvođenje logaritma i logaritamske funkcije sa stručno-matematičkog aspekta nije ni izbliza toliko izazovno kao uvođenje eksponencijalne funkcije. Početna razrada ove nastavne jedinice obično je korektno napravljena i udovoljava epistemološkim i metodičkim standardima. Standardni pristup je krenuti od definicije logaritma:

Definicija 7. Neka je $a \in \mathbb{R} i y \in \mathbb{R}$. Broj $x$ za kojeg vrijedi da je $a^{x}=y$ nazivamo logaritmom broja y po bazi a i pri tomu pišemo: $x=\log _{a} y$.

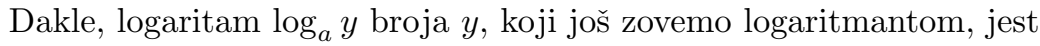
eksponent kojim treba potencirati bazu $a$ da bi se dobio $y$ :

$$
a^{\log _{a} y}=y
$$

Iako je iz početnih primjera računanja jednostavnijih logaritama to jasno, učenicima treba dodatno osvijestiti da je postupak "podizanja” nekog broja $x$ s nekom čvrstom bazom $a$, tj. postupak određivanja potencije 
$a^{x}=y$ nazvan eksponenciranje (ovaj se termin često brka s potenciranjem) inverzan postupku logaritmiranja. Postupak logaritmiranja podrazumijeva odredivanje eksponenta $\log _{a} y=x$ kojim treba potencirati bazu $a$ da bi se dobio $y$. Svakako treba naglasiti da na ovakav način definirani logaritmi ne postoje za svaku bazu ni za svaki $y$. Primjerice logaritam po bazi 1 postoji samo za broj 1 . Nadalje, za negativnu bazu logaritam postoji tek za neke brojeve koji su vrijednosti potencija s takvom bazom s cjelobrojnim eksponentom ili racionalnim eksponentom oblika $\frac{1}{n}$, za neparni $n \in \mathbb{N}$. Primjerice, $\log _{-2}(-8)=3 \mathrm{i} \log _{-27}(-3)=\frac{1}{3}$. Iz tog se razloga sve takve baze izbacuju iz razmatranja, iako sam pojam logaritma kao i potencije i za te baze ima smisla. Nadalje, budući da je potencija za nenegativnu bazu uvijek pozitivna, logaritmi postoje samo za pozitivne brojeve. Dakle, isto kao što se prvo uveo pojam potencije, a tek onda eksponencijalne funkcije, tako je metodički ispravno prvo definirati logaritam (čak i bez ograničenja na bazu), a tek onda, za svaki $a \in \mathbb{R}^{+} \backslash\{1\}$, uvesti logaritamsku funkciju $\log _{a}: \mathbb{R}^{+} \rightarrow \mathbb{R}$

$$
\log _{a}(x)=\log _{a} x
$$

koju nazivamo logaritamskom funkcijom po bazi $a$. Odmah se vidi da su eksponencijalna i logaritamska funkcija inverzne funkcije pa se logaritam može sasvim korektno uvesti i kao vrijednost logaritamske funkciju koju definiramo kao funkciju inverznu eksponencijalnoj. Na takav se način u srednjoj školi uvode, primjerice, arcus funkcije. Ipak, opisani je način primjereniji za srednjoškolca od ovog matematički elegantnijeg. Posebno se izdvajaju logaritamske funkcije po bazi 10 i $e$ iz skupa ostalih logaritamskih funkcija te za te funkcije imamo čak i rezervirane oznake log, odnosno ln (ova oznaka potječe od prvih slova latinskog naziva logaritmus naturalis). Važnost baze 10 prilično je jasna budući da je dekadski sustav standardni sustav u kojem i inače računamo. Međutim, učeniku najčešće ostaje nejasno zbog čega baza $e$ ima toliko važnu ulogu da pored svih ostalih baza, samo ta (uz bazu 10) ima specijalnu oznaku. Na to ćemo se posebno osvrnuti u četvrtom i petom odjeljku ovoga rada.

Logaritamska funkcija ima i neka bitna svojstva koja su posljedica svojstava eksponencijalne funkcije:

Teorem 8. Neka je a $\in \mathbb{R}^{+} \backslash\{1\}$. Logaritamska funkcija $\log _{a}$ je neprekidna bijekcija koja je strogo uzlazna za $a>1$ i strogo silazna za $a \in\langle 0,1\rangle$ i ima sljedeća svojstva:

(i) $\log _{a}(x \cdot y)=\log _{a} x+\log _{a} y$, za sve $x, y \in \mathbb{R}^{+}$

(ii) $\log _{a}\left(\frac{x}{y}\right)=\log _{a} x-\log _{a} y$, za sve $x, y \in \mathbb{R}^{+}$

(iii) $\log _{a}\left(x^{r}\right)=r \cdot \log _{a} x$, za sve $x \in \mathbb{R}^{+}, r \in \mathbb{R}$

(iv) $\frac{1}{r} \log _{a} x=\log _{a^{r}} x$, za sve $x \in \mathbb{R}^{+}, r \in \mathbb{R} \backslash\{0\}$. 
Težište je obrade ove nastavne jedinice, osim na usvajanju pojma logaritma te na definiciji i svojstvima logaritamske funkcije, obično stavljeno i na stjecanje vještine primjene gore navedenih svojstava. Tu je uz tehnicističko uvježbavanje potrebno kroz različite primjere učenicima ukazati na blagodati svojstava funkcije koja „zbroj pretvara u produkt”, a „razliku pretvara u kvocijent” (više o tome u odjeljku 5). Ipak, jedno je svojstvo bez nekog jasnog razloga manje zastupljeno u zadatcima. Radi se o svojstvu koje nam rješava problem određivanja logaritama po proizvoljnoj bazi (što je do nedavno bilo aktualno kod korištenja kalkulatora koji imaju samo tipke „log" ili „ln" a ne i tipku , $\left.\log _{a} "\right)$ :

$$
\log _{a} x=\frac{\log _{b} x}{\log _{b} a}, a, b \in \mathbb{R}^{+} \backslash\{1\}, x \in \mathbb{R}^{+} .
$$

Navedimo jedan nestandardni zadatak koji se rješava pomoću prethodnog svojstva kao i zanimljivu formulu koja proizlazi iz njega, a neophodna je u postupku rješavanja.

Zadatak: Riješi jednadžbu:

$$
x^{\log 5}+5^{\log x}=2 .
$$

Da bismo mogli riješiti ovaj zadatak koji se svodi na jednadžbu

$$
5^{\log x}=1
$$

moramo pokazati da vrijedi

$$
a^{\log _{b} c}=c^{\log _{b} a},
$$

$z a$ sve $a, b, c>0, b \neq 1$, a to slijedi po

$$
a^{\log _{b} c}=a^{\frac{\log _{a} c}{\log _{a} b}}=\left(a^{\log _{a} c}\right)^{\frac{1}{\log _{a} b}}=c^{\log _{b} a} .
$$

Iznova se postavlja pitanje kako, pažljivim odabirom zanimljivih primjera, učenicima približiti primjenu logaritamske funkcije u svakodnevnom životu. Logaritmi se pojavljuju u fizici kod mjerenja jakosti zvuka izražene u decibelima. Primjenu logaritamske funkcije možemo pronaći i u kemiji prilikom računanja $\mathrm{pH}$ vrijednosti neke tvari, odnosno mjere kiselosti ili lužnatosti neke vodene otopine. Očita je korelacija s drugim predmetima te bi se ovaj dio gradiva u suradnji s kolegama nastavnicima drugih predmeta mogao učiniti dodatno zanimljivim. Poslužiti nam može i korelacija s geografijom. Na području Splitsko-dalmatinske županije u posljednjih nekoliko godina manji su potresi česta pojava. Potresi nastaju pomicanjem litosfernih ploča na njihovim granicama. Takve se kretnje u zemlji mjere seizmografima. Jačina potresa povezana 
je s količinom energije koja se oslobađa za vrijeme njegovog trajanja. Postoje razne ljestvice koje mjere jačinu potresa, a među najpoznatijima su Mercallijeva i Richterova ljestvica. Richterovu ljesticu je razvio Charles F. Richter kao matematički uređaj za usporedbu jačine potresa. Na Richterovoj skali s brojem 2 izražavaju se potresi mikrojačine, a s 10 potresi ogromne razorne jačine, ali takvi potresi nisu nikada zabilježeni. Slovom $R$ označujemo mjeru magnitude potresa i računamo je formulom

$$
R=\log \frac{A}{A_{0}},
$$

gdje je $A_{0}$ amplituda najmanjeg vala koji se može otkriti pomoću seizmografa, a $A$ je mjera amplitude potresa. Zanimljivo je promatrati razliku amplituda između potresa različitih jačina u linearnoj skali i istu tu razliku između jačine potresa u Richterovoj skali. Potres jačine 6 ima za $9 \cdot 10^{5}$ veću amplitudu od potresa jačine 5 , a potres jačine 7 ima za $9 \cdot 10^{6}$ veću amplitudu od potresa jačine 6 , što je deset puta više u odnosu na razliku amplituda potresa jačine 6 i potresa jačine 5 . Za mjerne brojeve poput takvih koji su u logaritamskoj vezi s intezitetom mjernih svojstava kažemo da tvore logaritamsku skalu. Logaritamskom funkcijom možemo opisati pojave koje u početku brzo rastu ili padaju, a potom se rast, odnosno pad bitno usporava. Jedan od primjera iz svakodnevnog života, koji možemo opisati logaritamskim modelom, vezan je uz starost automobila. Vrijednost bilo kojega novoga automobila u početku naglo pada, a zatim se pad njegove vrijednosti usporava. Ovu pojavu možemo opisati logaritamskim modelom, i to logaritamskom funkcijom s nekom bazom manjom od 1. Nakon što odredimo odgovarajući logaritamski model, možemo približno odrediti vrijednost automobila u bilo kojem trenutku. Postavlja se pitanje kako iz zadanih podataka znati koji model možemo primijeniti. No, znamo da se logaritamskim modelom opisuju pojave kod kojih vrijednosti u početku ubrzano rastu ili padaju, a zatim se rast, odnosno pad usporava. Eksponencijalnim modelom opisujemo pojave kod kojih vrijednost u početku vrlo sporo rastu ili padaju, a onda se rast, odnosno pad, naglo ubrzava. Uz takve je pretpostavke jednostavnije odrediti funkciju koja će modelirati zadani problem, odnosno čiji će graf približno prolaziti kroz zadane točke dobivene iz dostupnih podataka.

\section{Različiti matematički aspekti eksponen- cijalne i logaritamske funkcije}

Eksponencijalna i logaritamska funkcija imaju mnoga lijepa svojstva. Većina njih zanimljiva su različitim, ne nužno matematičkim, profesijama koje ih koriste u mnogim primjenama. Ipak, s matematičkog su 
aspekta najzanimljivija ona svojstva koja ih i karakteriziraju i izdvajaju od svih ostalih neprekidnih realnih funkcija realne varijable.

\subsection{Homomorfizam}

Prisjetimo se da je homomorfizam funkcija koja operira između dvije grupe i čuva grupovne operacije.

Definicija 9. Neka su $(G, \cdot) i(H, *)$ dvije grupe. Preslikavanje $\phi: G \rightarrow$ $H$ za koje vrijedi $\phi(x \cdot y)=\phi(x) * \phi(y)$ je homomorfizam grupa.

Skup realnih brojeva zajedno sa zbrajanjem (i nulom kao neutralnim elementom) je grupa $(\mathbb{R},+)$. Isto je tako i skup pozitivnih realnih brojeva s množenjem (i jedinicom kao neutralnim elementom) grupa $\left(\mathbb{R}^{+}, \cdot\right)$. Po svojstvu $(i)$ teorema 3 i teorema 8 slijedi da su eksponencijalna i logaritamska funkcija homomorfizmi, odnosno izomorfizmi. Pitamo se kako izgledaju svi neprekidni homomorfizmi $f:(\mathbb{R},+) \rightarrow\left(\mathbb{R}^{+}, \cdot\right)$ osim trivijalnog (konstanta koja $\mathbb{R}$ preslika u 1). Dokazat ćemo da su eksponencijalne funkcije jedini netrivijalni neprekidni homomorfizmi izmedu ovih grupa, odnosno da je svojstvo homomorfizma vrlo rijetko svojstvo koje od svih neprekidnih funkcija između $\left(\mathbb{R},+\right.$ ) i $\left(\mathbb{R}^{+}, \cdot\right.$ ) (a samo takve su nam dovoljno lijepe $u$ elementarnoj matematici) imaju samo eksponencijalne funkcije. Stoviše, možemo reći ne samo da je to svojstvo ono koje smo u postupnom uvođenju potencija prepoznali kao esencijalno, već i da to svojstvo karakterizira eksponencijalnu funkciju.

Teorem 10. Neka je $\phi:(\mathbb{R},+) \rightarrow\left(\mathbb{R}^{+}, \cdot\right)$ neprekidni netrivijalni homomorfizam. Tada je $\phi=\exp _{a}$, gdje je $a=\phi(1)$. Drugim riječima, eksponencijalna funkcija $\exp _{a}$ jedini je neprekidni netrivijalni homomorfizam između $(\mathbb{R},+) i\left(\mathbb{R}^{+}, \cdot\right)$ koji 1 preslika $u$ a.

Dokaz. Označimo $a:=\phi(1)$. Pretpostavimo da je $a \neq 1$. Tada, za svaki $n \in \mathbb{N}$, po svojstvu homomorfizma slijedi

$$
\phi(n)=\phi(1+\cdots+1)=\phi(1) \cdot \ldots \cdot \phi(1)=a \cdot \ldots \cdot a=a^{n}
$$

i

$$
\phi(-n)=\phi(n)^{-1}=\left(a^{n}\right)^{-1}=a^{-n} .
$$

Nadalje, za svaki $n \in \mathbb{N}$ vrijedi

$$
a=\phi(1)=\phi\left(\frac{1}{n}+\cdots+\frac{1}{n}\right)=\phi\left(\frac{1}{n}\right) \cdot \ldots \cdot \phi\left(\frac{1}{n}\right)=\phi\left(\frac{1}{n}\right)^{n},
$$

pa je

$$
\phi\left(\frac{1}{n}\right)=\sqrt[n]{a}=a^{\frac{1}{n}}
$$


Po svojstvu homomorfizma, za svaki $m, n \in \mathbb{N}$, vrijedi

$$
\phi\left(\frac{m}{n}\right)=\phi\left(\frac{1}{n}\right)^{m}=\left(a^{\frac{1}{n}}\right)^{m}=a^{\frac{m}{n}},
$$

odnosno

$$
\phi\left(-\frac{m}{n}\right)=\phi\left(\frac{m}{n}\right)^{-1}=a^{-\frac{m}{n}} .
$$

Time smo dokazali da je $\left.\phi\right|_{\mathbb{Q}}=\left.\exp _{a}\right|_{\mathbb{Q}}$. Sada, zbog neprekidnosti funkcija $\phi$ i $\exp _{a}$ po teoremu 4 slijedi $\phi=\exp _{a}$. Pretpostavimo sada da je $a=1$. Tada je $\left.\phi\right|_{\mathbb{Q}}$ konstantna funkcija, a onda je po teoremu 4 i $\phi$ konstanta, tj. trivijalni homomorfizam, što se protivi pretpostavci teorema.

\subsection{Populacijska diferencijalna jednadžba}

Tražimo realnu funkciju realne varijable kojoj je omjer funkcijskih vrijednosti za isti prirast $\Delta x$ uvijek isti,

$$
\frac{f\left(x_{1}+\Delta x\right)}{f\left(x_{1}\right)}=\frac{f\left(x_{2}+\Delta x\right)}{f\left(x_{2}\right)}
$$

odnosno, želimo da kvocijent

$$
\frac{f(x+\Delta x)}{f(x)}=g(\Delta x)
$$

ovisi samo o prirastu $\Delta x$, pri čemu je $g(0)=1$. Nadalje, tražimo da funkcija bude derivabilna i da vrijedi $f(x) \neq 0$ za svaki $x$ iz domene. Derivacijom jednakosti (7) po $x$ dobijemo

$$
\frac{f^{\prime}(x+\Delta x) \cdot f(x)-f(x+\Delta x) \cdot f^{\prime}(x)}{f^{2}(x)}=0 .
$$

Prethodna je jednakost zadovoljena ako i samo ako vrijedi

$$
f^{\prime}(x+\Delta x) \cdot f(x)-f(x+\Delta x) \cdot f^{\prime}(x)=0 .
$$

Derivacijom (7) po $\Delta x$ izlazi

$$
\frac{1}{f(x)} \cdot f^{\prime}(x+\Delta x)=g^{\prime}(\Delta x),
$$

odnosno

$$
f^{\prime}(x+\Delta x)=f(x) \cdot g^{\prime}(\Delta x) .
$$

Uvrštavanjem (9) u (8) dobijemo

$$
f(x) \cdot g^{\prime}(\Delta x) \cdot f(x)-f(x+\Delta x) \cdot f^{\prime}(x)=0 .
$$


Sada, iz (7) slijedi

$$
f^{2}(x) \cdot g^{\prime}(\Delta x)=g(\Delta x) \cdot f(x) \cdot f^{\prime}(x) .
$$

i

$$
\frac{g^{\prime}(\Delta x)}{g(\Delta x)}=\frac{f^{\prime}(x)}{f(x)} .
$$

Budući da $\frac{g^{\prime}(\Delta x)}{g(\Delta x)}$ ovisi samo o čvrstom $\Delta x$, slijedi da je

$$
\frac{g^{\prime}(\Delta x)}{g(\Delta x)}=\frac{f^{\prime}(x)}{f(x)}=C \in \mathbb{R},
$$

za svaki $x$ iz domene. Stoga je

$$
f^{\prime}(x)=C \cdot f(x) .
$$

Uvjet (7) nas je doveo do diferencijalne jednadžbe

$$
y^{\prime}=C \cdot y,
$$

koju nazivamo populacijskom jednadžbom i kojoj očigledno udovoljuje konstantna funkcija $y=0$. Pronađimo sada netrivijalna rješenja ove diferencijalne jednadžbe sa separiranim varijablama. Iz prethodnog izraza slijedi

$$
\begin{aligned}
\frac{d y}{y} & =C \cdot d x, \\
\frac{d y}{y} & =C \cdot d x \quad / \int, \\
\ln |y| & =C x+\ln C_{0}, \quad C_{0} \in \mathbb{R}^{+}
\end{aligned}
$$

i

$$
|y|=C_{0} e^{C x}
$$

Stoga je

$$
y=C_{0} e^{C x}, \quad C_{0} \in \mathbb{R}^{+}, C \in \mathbb{R}
$$

rješenje populacijske jednadžbe. Dakle, eksponencijalna funkcija jedina je derivabilna funkcija za koju vrijedi uvjet (7). Primjerice, linearna funkcija nema svojstvo (7) vezano za konstantnost kvocijenata funkcijskih vrijednosti, već svojstvo vezano za konstantnost razlika

$$
f\left(x_{0}+\Delta x\right)-f\left(x_{0}\right)=f\left(x_{1}+\Delta x\right)-f\left(x_{1}\right),
$$

i to je jedina neprekidna funkcija za koju vrijedi to svojstvo. 


\section{Financijska matematika}

Puno je primjera primjene eksponencijalne funkcije $u$ različitim znanstvenim područjima. Zanimljiva je primjena eksponencijalne funkcije $u$ financijskoj matematici. Još u doba babilonske algebre pojavili su se izrazi za izračun složenih kamata koji su imali oblik eksponencijalne funkcije. Danas, kada se gotovo svi transferi novca odvijaju preko banaka, potrebno je poznavati neke osnove kamatnog računa, kako bismo bili svjesni načina tijeka novca. Možemo u banku uložiti određeni novac kojemu će se pripisivati kamate ili možemo posuditi određeni novac iz banke i plaćati naknadu za posuđenu glavnicu, što nazivamo kamatom. Kamatni račun dijeli se na jednostavni i složeni, a u oba rabimo oznaku $C_{0}$ za glavnicu, $I$ za kamatu, $C_{n}$ za stanje nakon $n$-tog razdoblja ukamaćivanja te oznaku $p$ za kamatnjak. Kod složenog kamatnog računa kamate se na kraju (dekurzivni kamatni račun) ili na početku (anticipativni kamatni račun) svakog razdoblja računaju na iznos koji je bio na kraju, odnosno početku, prethodnog razdoblja i one se u tom trenutku pripisuju ukupnom stanju. Zbog toga kažemo da se u složenom kamatnom računu obračunavaju i „kamate na kamate”. Ako je $p$ godišnji kamatnjak, onda je iznos kamata nakon jednog obračunskog razdoblja, tj jedne godine:

$$
I_{1}=\frac{C_{0} \cdot p}{100} .
$$

Konačna vrijednost glavnice na kraju prve godine jednaka je

$$
C_{1}=C_{0} \cdot r,
$$

gdje se $\operatorname{broj} r=1+\frac{1}{100}$ naziva dekurzivnim kamatnim faktorom. Kamate na kraju $n$-tog razdoblja iznose

$$
I_{n}=\frac{C_{n-1} \cdot p}{100},
$$

pa za svaki $n \in \mathbb{N}$ vrijedi:

$$
C_{n}=C_{0} \cdot r^{n} .
$$

Ako uz godišnji kamatnjak $p$ kapitalizaciju izvodimo mjesečno, onda je jedna od mogućnosti uzeti tzv. relativni kamatnjak $\frac{p}{12}$ i primijeniti složeni kamatni račun za razdoblje od 12 mjeseci:

$$
C_{12}=C_{0}\left(1+\frac{p}{12 \cdot 100}\right)^{12} .
$$

Općenito, želimo li godinu podijeliti na $m$ jednakih intervala vremenskih razdoblja i kapitalizaciju izvoditi $m$ puta godišnje, stanje nakon godine dana bi bilo

$$
C_{m}=C_{0}\left(1+\frac{p}{m \cdot 100}\right)^{m} .
$$


Želimo li da se kapitalizacija odvija neprekidno, tj. da između dva obračuna kamata i njihovog pribrajanja kapitalu nema vremenskog diskontinuiteta, onda govorimo o neprekidnoj ili kontinuiranoj kapitalizaciji. U tom se slučaju odgovarajući iznos nakon jedne godine dobiven takvom kontinuiranom kapitalizacijom dobije dijeljenjem godine na beskonačno mala vremenska razdoblja, odnosno djelovanjem graničnog procesa $\lim _{m \rightarrow \infty}$ :

$$
\begin{aligned}
\lim _{m \rightarrow \infty} C_{m} & =C_{0} \lim _{m \rightarrow \infty}\left(1+\frac{p}{m \cdot 100}\right)^{m} \\
& =C_{0} \lim _{m \rightarrow \infty}\left(1+\frac{1}{m \cdot \frac{100}{p}}\right)^{m \cdot \frac{100}{p} \cdot \frac{p}{100}} \\
= & C_{0}\left(\lim _{m \rightarrow \infty}\left(1+\frac{1}{m \cdot \frac{100}{p}}\right)^{m \cdot \frac{100}{p}}\right)^{\frac{p}{100}}=C_{0} e^{\frac{p}{100}} .
\end{aligned}
$$

Tada je odgovarajući iznos nakon $n$ godina jednak

$$
C_{n}=C_{0} \cdot e^{\frac{n p}{100}},
$$

gdje se $e^{\frac{n p}{100}}$ naziva faktor rasta.

Kontinuirana kapitalizacija ima široku primjenu u praksi. Recimo da investitor želi zatvoriti račun na dan kada nema pripisa kamata. Točnu vrijednost investicije potrebno je znati u vremenskim trenutcima između ukamaćivanja primjenom gornje formule. Sav prirodni prirast može se izračunati pomoću kontinuiranog ukamaćivanja. Između ostaloga, demografi se ovom formulom služe za anticipiranje povećanja ili smanjenja populacije.

\section{Logaritamske tablice}

Otkriće logaritama u prvom redu možemo zahvaliti tablicama koje su rabili bankari. Te su tablice na neki način služile kao pomoć za brzo računanje, odnosno za svođenje množenja na zbrajanje (na tom principu izvođenja računskih operacija rade i današnja računala). Naime, zamislimo da treba pomnožiti dva broja $x_{1}$ i $x_{2}$ takva da je $y_{1}=\log x_{1}$ i $y_{2}=\log x_{2}$ i da su te vrijednosti zabilježene u tabličnim stupcima kao logaritmi i logaritmanti (,antilogaritmi”). Tada, za dobivanje traženog umnoška, dovoljno je zbrojiti $y_{1}+y_{2}$ i pronaći vrijednost antilogaritma od $y_{1}+y_{2}$ u tablici . Zaista, vrijedi

$$
y_{1}+y_{2}=\log x_{1}+\log x_{2}=\log \left(x_{1} \cdot x_{2}\right) .
$$

Na takav su način logaritamske tablice svodile složeniju operaciju množenja na obično zbrajanje. No, praktična upotreba takvih tablica mogla je 
imati jedino smisla ako ona obuhvaća dovoljan broj logaritama i antilogaritama uz malu razliku između susjednih vrijednosti tako da se uvijek može pročitati približna vrijednost logaritma ili antilogaritma zadanog broja. Stoga se postavilo pitanje kako doći do finije razdiobe vrijednosti $x$ i $y$. U potrazi za finijom razdiobom vrijednosti $x$ brzo je postalo jasno da bazu logaritma $b$ treba uzeti tako da je što bliže jedinici. Burgi je za bazu izabrao 1.0001, a Napier 0.9999999. Uočimo da je

$$
b=1.0001^{10000}=\left(1+\frac{1}{10^{4}}\right)^{10^{4}} \approx e,
$$

što je aproksimacija broja $e$ do treće decimale. Primijetimo da po svojstvu (iv) teorema 8 iz $y=\log _{1.0001} x$ slijedi

$$
\frac{y}{10^{4}}=\frac{\log _{1.0001} x}{10^{4}}=\log _{b} x .
$$

Dakle, ako za bazu 1.0001 malim promjenama vrijednosti $x$ ne odgovaraju male promjene vrijednosti $y$, proporcionalnim umanjenjem vrijednosti $y$ dobit ćemo opet logaritamske vrijednosti za iste vrijednosti $x$, ali s finijom razdiobom vrijednosti $y$ i drugom bazom $b$. Odabirom početne baze koja je još bliža 1 , npr. $1+\frac{1}{n}$, gdje je $n=10^{1000}$, nakon gore opisanog proporcionalnog umanjenja za $10^{-1000}$ prirodno se dobije baza $b=\left(1+\frac{1}{10^{1000}}\right)^{10^{1000}} \mathrm{tj}$. logaritamska tablica za $y=\log _{b} x$. Očigledno, za dani konačni niz vrijednosti $x$ u logaritamskoj tablici s, po želji, malim udaljenostima između njegovih susjednih članova uzimanjem baze koja je dovoljno blizu broja $e$ dobit ćemo i niz logaitama, tj. vrijednosti $y$ s dovoljno malim udaljenostima između njegovih susjednih članova. Na takav se prirodan način povijesno ukazala potreba za uvođenjem prirodnog logaritma u logaritamskim tablicama, a Napierovi i Burgijevi logaritmi predstavljaju njegovu aproksimaciju.

\section{Nepoznato o poznatome}

Promotrit ćemo presječne točke krivulje $y=a^{x}$ i $y=\log _{a} x$ ovisno o bazi $a$. Broj presječnih točaka može biti $0,1,2$ ili 3 . Problem se svodi na proučavanje rješavanja sustava jednadžbi

$$
\left\{\begin{array}{l}
y=a^{x} \\
y=\log _{a} x
\end{array}\right.
$$

što je ekvivalentno jednadžbi

$$
a^{x}=\log _{a} x
$$


ovisnoj o $a \in \mathbb{R}^{+} \backslash\{1\}$. Iako ovaj problem pripada elementarnom calculusu, on obično nije dovoljno detaljno razmotren na matematičkim studijskim programima na sveučilištima širom svijeta. Štoviše, studenti matematike i mnogi matematičari skloni su misliti da se krivulje ne presijecaju za $a>1$, a sijeku se u jednoj točki za $a \in\langle 0,1\rangle$.
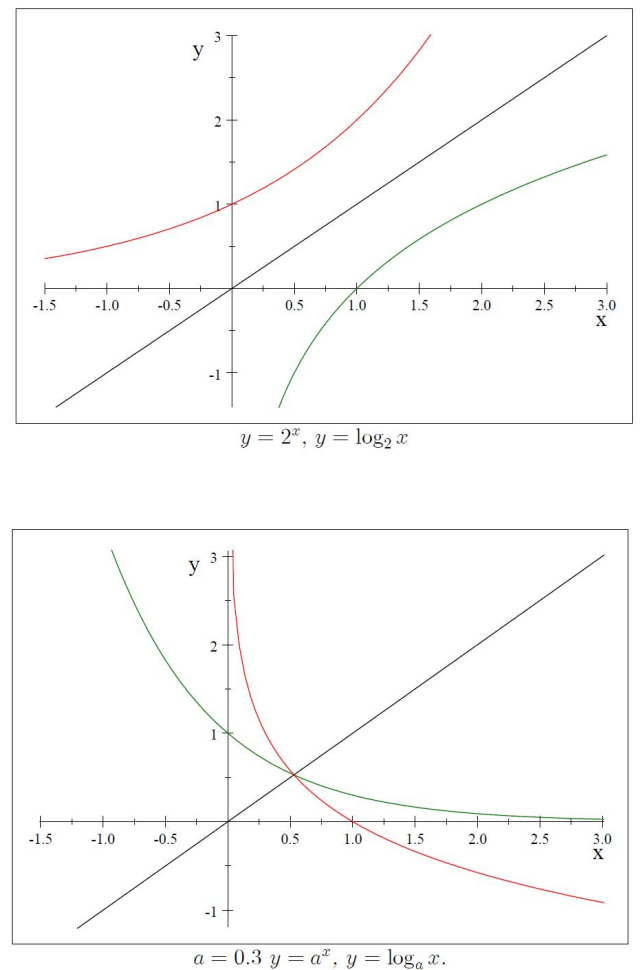

Takav dojam stvaraju mnogi udžbenici u kojima se za bazu $a$ uobičajno uzimaju brojevi $a=2, e, 10, \ldots$, kao standardni primjer eksponencijalne i logaritamske funkcije. Čak se u matematičkoj literaturi može pronaći tvrdnja da se grafovi funkcija $f(x)=a^{x}$ i $g(x)=\log _{a} x$ za $a \in\langle 0,1\rangle$ sijeku u jednoj točki. Na prvi pogled to se doima kao istinita tvrdnja jer ova tvrdnja vrijedi za neke standardne baze kao što su $\frac{1}{2}, e^{-1}, \ldots$ Međutim, protuprimjerom možemo pokazati da dana tvrdnja ne vrijedi. Za protuprimjer možemo uzeti bazu $a=\frac{1}{16}$. Tada vrijedi

$$
\log _{\frac{1}{16}} \frac{1}{4}=\frac{1}{2}, \quad\left(\frac{1}{16}\right)^{\frac{1}{4}}=\frac{1}{2}
$$




$$
\log _{\frac{1}{16}} \frac{1}{2}=\frac{1}{4}, \quad\left(\frac{1}{16}\right)^{\frac{1}{2}}=\frac{1}{4}
$$

Očito su $\left(\frac{1}{4}, \frac{1}{2}\right)$ i $\left(\frac{1}{2}, \frac{1}{4}\right)$ presječne točke grafova funkcija $f(x)=\left(\frac{1}{16}\right)^{x}$ i $g(x)=\log _{\frac{1}{16}} x$. Budući da se obje krivulje moraju s pravcem $y=x$ „susresti” u istoj točki, zaključujemo da postoje barem tri presječne točke.

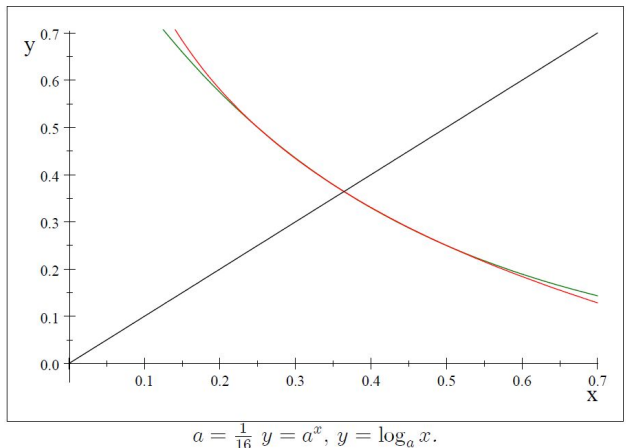

Vrijedi sljedeći rezultat:

Teorem 11. Jednadžba (10):

(i) nema rješenja ako je $a \in\langle\sqrt[e]{e},+\infty\rangle$

(ii) ima točno jedno rješenje ako je $a \in\left[\frac{1}{e^{e}}, 1\right\rangle \cup\{\sqrt[e]{e}\}$

(iii) ima točno dva rješenja ako je $a \in\langle 1, \sqrt[e]{e}\rangle$

(iv) ima točno tri rješenja ako je $a \in\left\langle 0, \frac{1}{e^{e}}\right\rangle$.

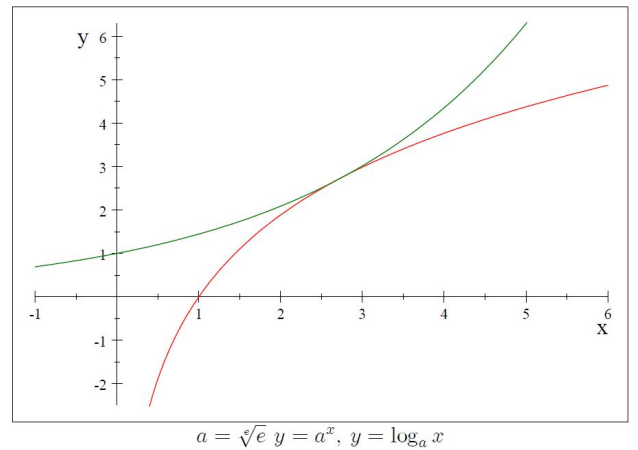



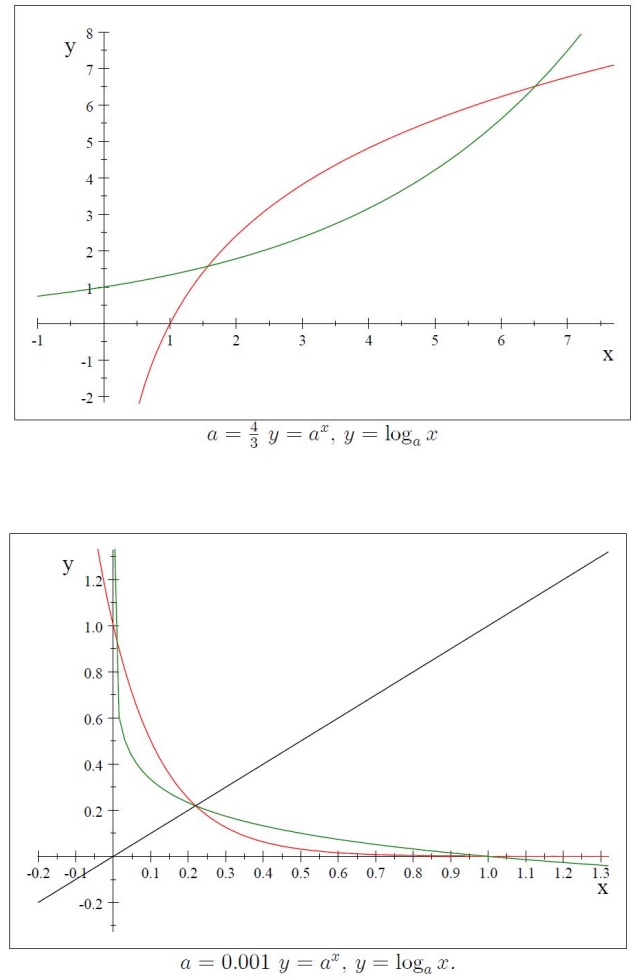

Osim rezultata iz prethodnoga teorema koji je objavljen u [1] i koji otkriva relativno nepoznata svojstva eksponencijalne i logaritamske funkcije, zanimljivo je i pojavljivanje broja e u granicama gornjih intervala. Ovaj, kao i primjeri iz prethodna dva odjeljka slikovito prikazuju važnost broja e u matematici, a njegovo pojavljivanje pri opisivanju različitih prirodnih procesa opravdava izraz prirodna baza, tj. prirodni logaritam za logaritme po bazi $e$.

\section{Literatura}

[1] N. Koceić Bilan, I. Jelić, On intersections of the exponential and logarithmic curves, Annales Mathematicae et Informaticae 43 (2014) pp. $159-170$ 
[2] Ivana Lončar, Različiti pogledi na eksponencijalnu i logaritamsku funkciju, diplomski rad, Prirodoslovno-matematički fakultet u Splitu (2019)

[3] Nacionalni kurikulum nastavnog predmeta Matematika, Ministarstvo znanosti i obrazovanja (2018)

Nikola Koceić-Bilan

Prirodoslovno-matematički fakultet Sveučilišta u Splitu

E-mail adresa: koceic@pmfst.hr

Ivana Lončar

Elektrotehnička škola Split

E-mail adresa: anaviloncar@gmail.com 